\title{
Settlement of A Corruption Criminal Offence Based on the State's Financial Loss Value Using An Economic Analysis of the Law
}

\author{
Samsul Huda ${ }^{1 *}$ Prija Djatmika ${ }^{2} \quad$ Bambang Sugiri $^{2} \quad$ Siti Hamidah $^{2}$ \\ 1. PhD. Candidate at Faculty of Law, Brawijaya University, Indonesia \\ 2. Lecturer at Faculty of Law, Brawijaya University, Indonesia
}

\begin{abstract}
The purpose of this research is analyze and find alternative models of arrangements for the resolution of corruption that are detrimental to the country's finances in the future based on economic analysis of the law. This research uses normative legal research methods with the statute approach, comparative approach, case approach and conceptual approach. The analytic technique of this research is using library research. The results showed that ineffectiveness and efficiency in law enforcement occur against corruption, the value of which is less than the cost of law enforcement. The researcher recommends a resolution model, first adopting a case resolution model which consists of a case resolution model outside the court proceeding with a modified transaction offer resulting from an economic analysis of the application of the law to the suspect, by creating a mechanism in a separate technical regulation and a restorative justice settlement model by modifying the application of the perpetrators' obligations for victims in the form of returning damages worth the amount that was corrupted, plus payment of the minimum fines stated in the law, and the value of indirect losses and the relative risk of law enforcement. Second Adopt a model of criminal implementation through the mechanism of payment of fines that are applied to traffic violations, by establishing a special current account set by the state and a mechanism of criminal social work to pay compensation for state losses. The deterrence and education effects of other communities can be stimulated through the imposition of an obligation to recover damages worth being corrupted; pay the minimum penalty stated in the law; pay for the relative risk of law enforcement; pay an indirect loss in the form of a difference in the difference in the amount of change in value of the corrupted state money calculated according to economic value when the legal process is in progress.
\end{abstract}

Keywords: Alternative Models, Corruption Crime Settlement, Economic Analysis of the Law.

DOI: $10.7176 / \mathrm{JLPG} / 93-11$

Publication date: January $31^{\text {st }} 2020$

\section{A. Introduction}

Promoting public welfare is a constitutional mandate. ${ }^{1}$ General welfare can be achieved through the implementation of good governance (the principles of good administration) and good financial governance (the principles of good financial governance). The implementation is (1) the effectiveness of activities, (2) financial efficiency, ${ }^{2}(3)$ increased role of control functions, ${ }^{3}(4)$ economic stabilization ${ }^{4}$ through optimizing financial functions, ${ }^{5}$ and (5) financial management ${ }^{6}$ according to basic principles, general principles, and statutory regulations.

Legislation is formed to stimulate behavior in the direction the state expects. That is, the frame for implementing law enforcement is prepared by considering (1) the purpose of making law, (2) the benefits of law enforcement itself; and (3) their influence on the perpetrators and the community. ${ }^{7}$ Paying close attention to the political politics of the Law on Eradication of Corruption (PTPK) which tends to contribute to the economic contribution, law enforcement against corruption does not merely imprison the perpetrators but rather safeguard the value that the PTPK Law intends to safeguard, namely eradicating corruption, and recovering state losses, to create high efficiency in order to realize economic growth and national development. The output is general welfare.

But in reality, the practice of law enforcement (punishment) has not had an effect on improving morality and corruption is growing more widespread, the state loss is not fully recovered and there is a tendency for leakage of state money in the law enforcement sector because the value of the loss saved is smaller than the

\footnotetext{
${ }^{1}$ Opening of the 1945 Constitution of the Republic of Indonesia, fourth century.

${ }^{2}$ Article 23 paragraph (1) of the 1945 Constitution of the Republic of Indonesia, 3rd amendment.

${ }^{3}$ In consideration of the formation of Law No. 17 of 2003 concerning state finances, that the implementation of state government to realize the objectives of the state raises state rights and obligations that can be valued in money.

${ }^{4}$ Elucidation of Article 3 paragraph (4) of Law No. 17 of 2003 concerning state finances, that state finance as a function of stabilization, makes the government budget as a tool to maintain and strive for economic fundamental balance.

${ }^{5}$ According to Article 3 paragraph 4 of Law No. 17 of 2003 concerning state finances, that the APBN / APBD has the functions of authorization, planning, supervision, allocation, distribution and stabilization. The definition of the financial function is then explained in the explanation of Article 3 paragraph 4 of Law No. 17 of 2003 concerning state finances.

${ }^{6}$ Article 3 paragraph (1) of Law No. 17 of 2003 concerning state finances.

${ }^{7}$ M. Ali zaidan, Kebijakan kriminal, Sinar grafika, Jakarta, 2016.
} 
economic value of the state's economy missing. The impact is not created high efficiency for economic growth and national development, but rather adds to the burden of state expenditure that does not contribute to the state.

The use of the budget is an inseparable part of the country's economic value. Even though Article 4 of the PTPK Law states that returning a state loss does not eliminate criminal penalties, the use of its law enforcement budget must be as efficient and economical as article 3 of the State Finance Law (KN), so as not to be inconsistent with Article 23 paragraph (1) of the 1945 NRI Constitution amendments to-3; Article 3 of the KN Law; Article 5 paragraph (3) and Article 30 paragraph (3) of Law no. 7 of 2006 concerning Ratification of the United Nations Anti-Corruption Convention, 2003; Perpres No. 54 of 2018 concerning the National Strategy for Corruption Prevention; 7th Instruction Inpres No. 5 of 2004 concerning the Acceleration of Corruption Eradication. The reality of inconsistency encourages the need to do a review of the limits of the use of criminal law with a test to reduce its economic value through rationality, effectiveness, efficiency, utility, and transaction $\operatorname{costs}^{1}$ so that it does not potentially cause leakage of state finances. ${ }^{2}$ The effectiveness and efficiency of law enforcement transaction costs should not merely consider instrumental theory and criminal law policy theory. ${ }^{3}$ The "economic analysis of the law" approach is important and is needed to maximize the effectiveness of the law to prevent corruption in the law enforcement sector. ${ }^{4}$

Based on the background that has been explained above, the purpose in this paper is to analyze and find alternative models for the management of corruption that harm the country's finances in the future based on economic analysis of the law. So that it is expected that the existence of an alternative model can be input for formulating improvements to the PTPK Law; be input to build a legal system that creates harmonization between the 1945 Constitution of the Republic of Indonesia, the PTPK Law, and the KN Law, in the context of optimizing the handling of corruption and becoming a strategic input to APH and APIP in order to improve corrupt management practices effectively, without creating potential losses state finances.

\section{B. Research Method}

This type of research is normative juridical research, study the philosophy of eradicating corruption, recovering state losses, and high efficiency in order to realize economic growth and national development through an economic analysis approach to the application of its law. ${ }^{5}$ The research approach used is the statute approach, comparative approach, case approach and conceptual approach. ${ }^{6}$ The legal material from normative research can be divided into three namely,

1. Primary legal material, consists of the 1945 Constitution of the Republic of Indonesia, the PTPK Law, the KN Law, the KPK Law, the 2003 UNCAC ratification Act, the HAP Law, Presidential Instruction No. 5 of 2004 concerning the acceleration of corruption eradication.

2. Secondary legal law, books, scientific journals, articles, Strategic Plans to eradicate corruption, restorative justice, economic analysis of law, and guidelines for resolving criminal cases with restorative justice within the Police, which can answer the legal issues in this study.

3. Tertiary Law Materials are legal materials that provide an understanding of primary and secondary legal materials, including legal and political dictionaries, encyclopedias, empirical data, and others.

The technique of searching primary and secondary legal materials is done by studying literature and searching through the internet (internet searching). ${ }^{7}$ The analysis technique in this research is library reseacrh. ${ }^{8}$

\section{Results and Discussion}

The objectives of the PTPK Law are (1) eradicating criminal acts of corruption due to the detriment of the state, (2) law enforcement to recover state losses incurred, (3) the results of recovery of state losses are for high efficiency in order to realize economic growth and national development. The outcome is the realization of social welfare through the efficiency of government administration, economic growth and national development. Underlying this law, corruption must be carried out systematically and continuously, by unraveling the root of the problem. To study and analyze the harmony between the objectives of the establishment of the PTPK Law and its implementation, as well as the economic level of the results of its implementation, the authors chose to compare the practice of criminal law in two countries namely the Netherlands with the consideration that the

\footnotetext{
${ }^{1}$ John Kenedi, Kebijakan hukum pidana (penal policy) dalam sistem penegakan hukum di Indonesia, pustaka pelajar, Yogyakarta, 2017, hal 90-91.

${ }^{2}$ The 9th Directive Inpres No. 5 of 2004 states, ".. conducting a review and review of systems that have the potential to cause corruption in the scope of duties, authorities and responsibilities of each."

${ }^{3}$ Nazaruddin lathif, 'Teori Hukum Sebagai Sarana/Alat Untuk Memperbaharui Atau Merekayasa Masyarakat', Journal of Law Review Volume 3 Number 1, January-June 2017, pp. 76-77.

${ }^{4}$ Law No. 7 of 2006 concerning ratification of the UN anti-corruption convention, 2003, Article 5 paragraph (3) and Article 30 paragraph (3).

${ }^{5}$ Marzuki, Peter Mahmud. Penelitian Hukum (Jakarta : Kencana Prenada Media, 2011), p.35.

${ }^{6}$ Saifudin azwas, Sikap Manusia - Teori Dan Pengukurannya, pustaka pelajar, Yogyakarta, 2016, p. 138.

${ }^{7}$ Satjipto Rahadjo, Ilmu Hukum, (Bandung: Citra Aditya Bhakti, 2000), p. 255.

${ }^{8}$ Abdlatif and Hasbi Ali. Perihal Kaedah Hukum, (Bandung: Citra Aditya Bakti, 2010), p.9.
} 
Netherlands is the country that abandoned its legal products in Indonesia, and the United Kingdom as common law countries.

The politics of Dutch criminal law puts the purpose of punishment in 3 (three) cases, namely (a) the punishment is carried out as a form of retaliation for the perpetrators' actions, (b) the imposition of penalties to the perpetrators is in the context of making a deterrent effect, (c) the enforcement of criminal law is also intended for recovery loss of victims and/or their families left behind. British criminal law politics puts the goal of punishment in 2 (two) terms, namely (a) the benefits of law enforcement for the perpetrators, the public and the public interest (b) Law enforcement must be proportional and proportional to the results. Therefore, the implementation of discretion must consider the matters stipulated in article 4.12 The code for prosecutors, January 2013.

The politics of law and the legal system prevailing in the Netherlands and in the UK despite the legal system being different from the Indonesian state but have an identical objective with Indonesian law namely justice, certainty, usefulness in law enforcement. Although there is an identity in the objectives, the legal system is different, as follows:

a. Indonesian Criminal Law System

To achieve legal objectives, the Indonesian criminal law system regulates as follows:

1. In order for someone to be punished, there must be rules that govern before the act occurs (the principle of legality);

2. Termination of a criminal case can only be done, because it is not bored enough, it is not a crime and for the sake of law.

3. Postponement of prosecution can only be done in the event of a pre-judicial dispute (article 81 of the Criminal Code).

b. Dutch Criminal Law System

To achieve legal objectives, the Dutch criminal law system regulates as follows:

1. Implement effective management to avoid lengthy and complicated law enforcement processes;

2. Settlement of criminal cases outside the court by considering the adverse effects in the future, and the public interest factor does not want to;

3. Prosecution of criminals is only carried out with consideration of the seriousness of the crime, the factor of the suspect's error, the loss suffered by the victim, costs relevant to the outcome.

c. British Criminal Law System

To achieve legal objectives, the British criminal law system regulates as follows:

1. Granting discretionary authority to the Prosecutor, for the settlement of cases outside the court, make an assessment can be done/can not be done/postponed the prosecution in the public interest, the termination of action can be done if the punishment is deemed not necessary anymore;

2. The judge is given the authority to calculate the profit value obtained by the suspect illegally, but cannot review the Prosecutor's discretion decision.

3. Imposition of obligation to the offender to pay compensation to the victims or family left behind, and restitution for damage due to criminal acts committed. If the offender is unable to pay, then the work is not paid.

Paying attention to the identical goals and differences in the legal system, the author's thoughts encourage collaborating legal systems of the Netherlands, the United Kingdom and Indonesia to find alternatives to tackle corruption that are effective and have high efficiency values to realize economic growth and national development. The background thinking of the economic value has given rise to inspiration about the corruption prevention strategy model with an economic value calculation approach to the law, as follows:

\section{Alternative Case Settlement Mode}

The case settlement model in the Netherlands and the UK if related to the values to be protected by the PTPK Law, is very suitable to be adopted and modified with economic analysis of the law to improve legal policies in Indonesia in the context of overcoming corruption. Arrangement for settlement of cases outside court trials by modifying the transaction offer resulting from economic analysis of the application of the law to the suspect, can be done by first making a new legal umbrella based on the following provisions:

a. Article 2 number 4 of MPR Decree No VIII/MPR/2001 concerning recommendations on the policy direction on eradication and prevention of corruption, collusion and nepotism,

b. Article 2 number 7 of MPR Decree No VIII/MPR/2001 concerning recommendations on the policy direction on eradicating and preventing corruption, collusion and nepotism,

c. Article 23 paragraph 1 of the 1945 Constitution of the Republic of Indonesia the third amendment, 
d. Article 3 of Law No. 17 of 2003 concerning KN,

e. The eleventh instruction of Presidential Instruction number 5 of 2004 concerning the acceleration of corruption eradication, sequence number 1 specifically to the Minister of Finance,

f. The eleventh instruction of Presidential Instruction number 5 of 2004 concerning the acceleration of corruption eradication, sequence number 5 specifically to the Minister of Law and Human Rights,

g. Eleventh Instruction Inpres number 5 of 2004 concerning the acceleration of corruption eradication, serial number 9 specifically to the Attorney General of the Republic of Indonesia.

h. The eleventh instruction of Presidential Instruction number 5 of 2004 concerning the acceleration of corruption eradication, serial number 10 specifically to the Chief of the Indonesian National Police.

As for changes to regulations to cover the model of corruption settlement that can protect the values that the PTPK Law wants to protect, are as follows:

1) Changes to Laws and Regulations

a. Article 67 of Law No. 8 of 1981 concerning HAP plus 2 (two) paragraphs so that as a whole it reads: Paragraph 1 "the defendant or public prosecutor has the right to appeal against the first-level decision except against the acquittal, free from all legal claims relating to less matters precisely the application of the law and court decisions in a quick event. "Paragraph 2 of the provisions of paragraph 1 are exempt from decisions independent of all lawsuits against corruption cases whose value of loss is less than the cost of law enforcement and its relative risk, the defendant has returned the value of the corrupted amount, plus the cumulative amount of the minimum penalty stated in the law and the relative risk of loss from law enforcement. Paragraph 3 of the judge's decision as paragraph 2 is final.

b. Between article 109 and article 110 of Law No. 8 of 1981 concerning HAP, article 109A is inserted which reads: "termination of investigations into corruption cases other than those stated in article 109 paragraph 2, can be done because the value of state losses is less than the cost of law enforcement and the relative risk of law enforcement, while the suspect/defendant returns the value of the corrupted amount plus a minimum fine determined by the law and the relative risk value as stated in article 4 of the PTPK Law (concept of change). "

c. Article 222 paragraph 1 of Law No. 8 of 1981 concerning HAP, which states: "anyone who is convicted of a criminal is burdened with paying the case fee and in the case of a ruling free or free from all lawsuits, the case fee is charged to the state", is changed to:

"whoever is convicted is liable to pay a case fee, and in case of a ruling that is free or free from all lawsuits, the case fee is borne by the state, except for corruption cases whose value is less than the cost of law enforcement and the relative risk loss, the case cost as the relative risk is paid by the defendant at the defendant's request."

d. Between Article 5 and Article 6 of Law No. 46 of 2009 concerning the Corruption Criminal Court, Article 5A is inserted, which states, "Paragraph 1 of Article 5 is excluded from corruption cases whose loss value is less than the cost of law enforcement and its relative risk as stipulated in Article 4 of the Law PTPK (concept of change). Paragraph 2 As long as there is no corruption court in the district/city where the crime occurred, in order to realize a quick and low-cost court, the local District Court is given the authority to examine and try the case. Paragraph 3 of the examination in a district court according to the applicable criminal procedure law unless otherwise specified in the Act.

e. Article 4 of the PTPK Law which states: "restitution of state financial losses or the economy of the state does not eliminate criminal convictions as referred to in article 2 and article $3 "$ amended to 4 (four) paragraphs so that the whole becomes read:

Paragraph 1 restoring financial losses to the state or the economy of the state does not eliminate the criminal conviction of the offender;

Paragraph 2 The provisions in paragraph 1 are excluded in terms of:

- the corrupted value is less than the cost of law enforcement and its relative risk, and the perpetrator returns the amount of corruption corrupted plus the minimum penalty stated in the law, and the value of the indirect state loss caused by the perpetrator's actions, the judge can determine in his decision there is no penalty worn. If the case in an investigation or prosecution can be stopped by law and in the public interest.

- If the corrupted value is less than the cost of law enforcement and its relative risk, the offender is not willing to return the amount of the corrupted loss plus the minimum fine stated in the law along with the state loss value indirectly caused by 
the perpetrators' actions, to bring about a quick and low-cost trial, as long as there is no corruption criminal court in the district/city where the crime took place, the local District Court is given the authority to examine and try the case.

- In the event that the trial process is ongoing and the defendant returns the amount of corruption that has been incurred plus the minimum fine stated in the Act and the value of indirect state losses caused by the perpetrator's actions, the judge can determine that in his decision there is no penalty imposed.

Paragraph 3 Relative risks and indirect state losses due to the actions of the perpetrators as referred to in paragraph 2 are reimbursement of costs incurred by the state for law enforcement, and payment of shortages for the difference in the amount of value changes from corrupted state money is calculated according to economic value when the legal process runs.

Paragraph 4 Calculation of the relative risk and loss of the state is not immediately determined by the BPK or BPKP or APIP if the case is in the process of investigation or prosecution, and the Panel of Judges in the case of the case in the process of court hearing.

f. Article 18 paragraph 1 letter (b) of the PTPK Law, which states "in addition to the additional crimes referred to in the criminal law book, as an additional crime is the payment of a replacement money which is as much as the same as the price of the object obtained from the criminal act of corruption, "Amended because it must be interpreted and taken into account, including costs incurred as a relative risk of law enforcement, so Article 18 paragraph 1 letter (b) of the PTPK Law reads as follows:" paying as much compensation as the same value as being corrupted plus the cost law enforcement plus the relative risk arising from the corruption act "

g. Article 18 paragraph 3 of the PTPK Law, which states: "in the case of a convicted person not possessing sufficient property to pay the replacement money as referred to in paragraph (1) letter (b), then convicted with imprisonment whose duration does not exceed the maximum threat of the principal criminal in accordance with the provisions in this law and the length of time the criminal has been determined in a court decision "is amended to read:" in case the convict does not have sufficient assets to pay the replacement money as referred to in paragraph (1) letter (b), it must be serving additional sentence in the form of social work to pay a replacement money whose value is stated in a court decision."

h. Between article 34 and article 35 of the PTPK Law, plus article 34A reads:

Paragraph 1 In the case of the provisions of article 32 paragraph 1, article 33 and article 34 the party responsible for the loss of the state/region, or if he has died and his heirs have returned the loss of the country/region plus the relative risk arising as in article 4, then the case transfer to the State Attorney or the injured institution is deemed unnecessary.

Paragraph 2 With respect to the implementation of the provisions in paragraph 1 , the Investigator is obliged to deliver notification of the settlement of the case to the State Attorney Attorney and/or the Head of the aggrieved Agency.

i. Article 52 PP 38 of 2016 concerning the procedure for claiming compensation for state/regional claims against civil servants not treasurers or other officials, which states: "Any adverse party determined to compensate for state/regional losses may be subject to administrative sanctions and/or criminal sanctions" amended so that article 52 as a whole reads:

Paragraph 1 "Any adverse party determined to compensate for state/regional losses may be subject to administrative sanctions and/or criminal sanctions," unless they have returned the said state/region losses.

Paragraph 2 if the loss of the state/region occurs due to a crime, then the provisions of article 4 of the PTPK Law (concept of amendment) apply.

2) Changes to Regulations and Decisions

a. Between article 38 and article 39 of BPK Regulation number 3 of 2007 concerning procedures for settling state compensation for treasurers, article 38A is inserted which reads:

Paragraph 1 In the case that the value of state losses is less than the cost of criminal law enforcement and its relative risk, the provisions of article 4 of the PTPK Law (concept of amendment) apply.

Paragraph 2 If the value of the state's loss is greater than the cost of criminal law enforcement and its relative risk, the legal subjects responsible for the criminal responsibility shall be prosecuted according to the applicable laws and regulations.

b. Number 8 Instructions for joint implementation of the Attorney General of the Republic of 
Indonesia and Head of the Financial and Development Supervisory Agency Number: Juklak001/JA/2/1989, number: KEP-145/K/1989, concerning efforts to strengthen the cooperation between the prosecutor's office and BPKP in handling cases which indicated corruption, was amended and added a condition requirement so that as a whole it read: "the cessation of the investigation can only be carried out after obtaining approval from the Attorney General of the Republic of Indonesia and fulfilling the conditions specified in article 109 paragraph 2 of the Criminal Procedure Code" and article 4 of the PTPK Law (concept of amendment).

c. Between Article 6 and Article 7 a Memorandum of Understanding between the Attorney General's Office of the Republic of Indonesia, the Indonesian National Police, and the Financial and Development Supervisory Agency number: KEP-109/A/JA/09/2007, No. Pol .: B/2718/IX/2007, Number: KEP-1093/K/D6/2007 concerning cooperation in handling cases of irregularities in the management of state finances that indicate criminal acts of corruption including non-budgetary funds, Article $6 \mathrm{~A}$ is inserted, which reads:

"In the case of alleged corruption found in article 4 paragraph 4 and article 6 paragraph 4 , the value of the loss is less than the cost of law enforcement and the relative risk of law enforcement, while the party responsible for returning the value of the corrupted value plus a minimum fine is determined by law, as well as the relative risk value as stated in article 4 of the PTPK Law (concept of change), the case applies to the provisions of article 4 of the PTPK Law (concept of change). "

d. Between Article 7 and Article 8 the Cooperation Agreement between the Ministry of Home Affairs of the Republic of Indonesia and the Attorney General's Office of the Republic of Indonesia, and the Indonesian National Police Number: 119-49 YEAR 2018, Number: B369/F/Fjp/02/2018, Number: B/9/II/2018, concerning the coordination of the government's Internal Supervisory Apparatus (APIP) with the APH (APH) in handling reports or complaints from the public which indicate criminal acts of corruption in the administration of regional government, Article 7A is inserted, which reads:

"In the case of the parties either individually or jointly finding allegations of a criminal act of corruption the value of the loss is less than the cost of law enforcement and the relative risk of law enforcement, while the party responsible for returning the value of the corrupted losses plus the minimum fine determined by the law law, as well as the relative risk value as stated in article 4 of the PTPK Law (concept of change), then the provisions of article 4 of the PTPK Law (concept of change)."

Based on the basic norms and changes in the laws and regulations, the main ideas in the corruption case resolution model can be formulated as follows:

1) Model of settlement of cases outside court trials with modification of transaction offers resulting from economic analysis of the application of the law to suspects. The mechanism for applying the case settlement model outside the court with transaction modification,

a. If the case is still under investigation and evidence of alleged corruption has been found to be detrimental to the country's finances, the steps are as follows:

- After receiving a request for settlement of a case out of court from the party responsible for state/regional losses, the investigator coordinates with APIP to conduct an investigative audit to determine the value of the state losses incurred.

- Make an investigation plan and an investigation budget plan (RAB) to determine the cost of an investigation. While the value of the costs of prosecution, court hearings and enforcement of decisions in correctional institutions, calculations can be requested from the State Attorney.

- In the case of law enforcement costs greater than the value of state losses incurred, the investigator coordinates with APIP and/or BPK, and/or BPKP to conduct an economic analysis of the implementation of criminal law.

- The report on the results of the economic analysis of the implementation of the law is then used as the value offered to the party responsible for state losses.

- In the event that the party responsible for the loss returns the state losses incurred in addition to an indirect loss in the form of a relative risk to the giro account set by the state, the action shall not be subjected to and the investigation of the case shall be terminated.

- If the party responsible for the loss does not want to pay, the case will be upgraded to the investigation stage.

b. Case in the investigation and or prosecution stage:

- after receiving a request for settlement of a case outside the court that is filed by a responsible party/suspect/defendant, the investigator and/or the public prosecutor 
conducts administrative research as a formal requirement for the settlement of a case outside the court

- Requests that meet the formal requirements are submitted to the supervisor of the investigator (if the case is in the investigation of the National Police), or to Kajar/Kajati (if the case is in the investigation of the prosecutor's office or the prosecution stage). If the application does not meet the requirements, then return it to the applicant accompanied by a written explanation.

- Investigators and/or public prosecutors in accordance with the level of examination of the case carry out a special case title by presenting the State Attorney to determine whether or not the feasibility of being settled out of court

- In the case of a special case title agreeing to be settled outside the court, based on the recommendation of the special case title, the investigator and/or public prosecutor shall submit the calculation of economic analysis to the implementation of the law to the $\mathrm{BPK} / \mathrm{BPKP} / \mathrm{APIP}$ to determine the relative loss value of the case if law enforcement is carried out.

- In case the economic analysis calculation report on the implementation of the law has been completed and received by the investigator and/or public prosecutor, and a copy has also been sent to the State Attorney, then the investigator and/or public prosecutor in accordance with the level of examination of the case notifies the applicant (the party responsible/suspect/defendant)

- If the responsible party/defendant/defendant agrees, within 30 (thirty) days must return state losses, fines, and losses relative to law enforcement in accordance with the results of economic analysis of the law made by BPK/BPKP/APIP to the state current account .

- Investigators and/or public prosecutors in accordance with the level of examination of the case carry out the termination of the investigation/prosecution by law and in the public interest.

An alternative model of dispute resolution resolution in the Court by modifying the application of the perpetrators' obligations to the state in the form of returning damages worth the amount that was corrupted, plus payment of the minimum fines stated in the law, and the value of indirect losses and the relative risk of law enforcement. The mechanism of its implementation;

- $\quad$ The application is submitted to the Public Prosecutor with a copy of the State Attorney

After receiving the request for settlement of a case outside the court that was submitted by the defendant, the Public Prosecutor conducted an administrative study which was a formal requirement for the settlement of the case with an alternative dispute resolution.

in case formal requirements are met, the Public Prosecutor follows up by requesting a calculation of economic analysis of the law from the BPK/BPKP.

Based on the approval of the State Attorney, the Public Prosecutor submits the settlement of the case to the Panel of Judges by attaching a report on the results of the calculation of state losses, and the results of the calculation of economic analysis of the law are then used as a material for judges to make decisions about the value of state losses and the relative risks involved. arise from law enforcement.

The panel of judges opened a mediation room and delivered it to the defendant before the Public Prosecutor and the State Attorney. In the event that the defendant approves and returns a loss of the value that was corrupted plus a minimum fine stated in the law, and a loss of the relative risk of law enforcement, the judge stated in his decision that there was no action against the defendant (free from all lawsuits).

If the defendant is unable to pay in part, or in whole, then the hearing continues until the judge's decision is obtained. In case the verdict is proven guilty, then the convicted person must execute the judge's decision (including social work to restore the economic value that becomes a loss).

2. Alternative Criminal Implementation Models

1) The criminal procedure model adopts a fine payment mechanism that is applied to traffic violations and violations in article 82 of the Criminal Code, by establishing a special current account set by the state. The mechanism is as follows,

a. After examining the case on the agenda of resolving the case with the loss recovery transaction reaching the point of agreement, the judge handed down the interim decision.

b. Within a period of 14 (fourteen) days the defendant must pay to the state giro account the amount agreed upon and decided in the interim decision.

c. In the case that the defendant pays to the state giro account in the amount agreed upon and 
decided in an interim decision, the judge reopens the examination of the case to issue a final decision.

d. The final verdict is free from all lawsuits. In the event that the defendant is subject to prior detention, it is issued by law.

2) The criminal implementation model adopts a social work criminal mechanism to pay compensation for state losses. The social work criminal model is intended for convicts who are unable to recover state losses. The mechanism is as follows,

a. The execution of social work penalties is outside the time of the execution of the main sentence;

b. A social workplace is a special place for inmates held by a prison;

c. The length of additional sentences for undergoing social work and working hours each day is determined in the judge's decision;

d. The social work is calculated based on the work output, which is then reconciled with the value that must be paid to the state;

e. In the event that the additional sentence is not over but the convicted person has paid off his obligation to pay damages to the state, then the implementation of the social work law will be terminated;

f. The Public Prosecutor as the executor of the judge's decision is authorized to stop the implementation of social punishment.

3. Alternative Forms of Achieving Deterrence

As a form of attaining deterrence and education effects for other communities so as not to commit corruption, in the case settlement model outside the court weights are imposed in fines, i.e. in addition to returning damages worth being corrupted, the perpetrators are liable to; pay the minimum fine stated by law, pay for the relative risk of law enforcement, and pay an indirect loss in the form of a difference in the difference in the amount of change in value of the corrupted state money calculated according to economic value when the legal process is in progress.

\section{Conclusions}

Corruption prevention must be based on the social, cultural, political and economic conditions of the nation, because nation building is not criminogenic that ignores cultural values, morals and social defense strategies. Corruption prevention must be rational, protecting the values that the PTPK Law wants to protect, in line with the country's goals mandated in the constitution. When the concept of deterrence is ineffective and instead burdensome economic development productivity, the PTPK Law is no longer responsive to the economic and social system. The implementation of the PTPK Law does not protect the values that the PTPK Law wants to protect and is not in line with the country's goals, so it is not effective in preventing corruption. Under these conditions, the state must formulate an effective strategy for tackling corruption, which provides protection of the interests of the community, the state, and its positive positive effects in the future.

Meeting these standards, an alternative model for resolving corruption is proposed, which has a smaller loss than the cost of law enforcement and its relative risk, namely adopting a case resolution model and adopting a criminal implementation model. As a form of attaining deterrence and education effects for other communities so as not to commit corruption, even though there are no criminal offenses (prison/confinement) in the model of settlement of corruption cases, there is an imposition of weighting in fines, that is, in addition to returning losses worth the corrupted, the perpetrators incurred the obligation to pay the minimum fines stated in the law. pay the relative risk of law enforcement and pay for indirect losses in the form of a shortfall in the difference in the amount of change in the value of the corrupted state money calculated according to economic value when the legal process is running.

\section{Reference}

Abdlatif and Hasbi Ali. Perihal Kaedah Hukum, (Bandung: Citra Aditya Bakti, 2010).

John Kenedi, Kebijakan hukum pidana (penal policy) dalam sistem penegakan hukum di Indonesia, (Yogyakarta: pustaka pelajar, 2017).

Marzuki, Peter Mahmud. Penelitian Hukum (Jakarta: Kencana Prenada Media, 2011).

M. Ali zaidan, Kebijakan kriminal, (Jakarta: Sinar grafika, 2016).

Nazaruddin lathif, "Teori Hukum Sebagai Sarana/Alat Untuk Memperbaharui Atau Merekayasa

Masyarakat", Journal of Law Review, 2017, 3(1): 76-77.

Satjipto Rahadjo, Ilmu Hukum, (Bandung: Citra Aditya Bhakti, 2000).

Saifudin azwas, Sikap Manusia-Teori Dan Pengukurannya, (Yogyakarta: pustaka pelajar, 2016).

\section{Laws And Regulations}

Indonesia, Presidential Instruction number 5 of 2004 concerning the acceleration of corruption eradication. 
Indonesia, the Constitution of the Republic of Indonesia, 1945.

Indonesia, Law No. 17 of 2003 concerning state finances.

Indonesia, Law No. 7 of 2006 concerning the ratification of the UN anti-corruption convention. 